\title{
Convents without Nuns: \\ Historical Analysis of Women Workers in a Textile Factory
}

Rafael Diogo Pereira ${ }^{1}$ Andressa Carolina do Nascimento Nunes ${ }^{1}$

Thaís Zimovski Garcia de Oliveira ${ }^{1}$

Universidade Federal de Minas Gerais, Belo Horizonte, MG, Brazil ${ }^{1}$

Received 21 May 2018. This paper was with the authors for two revisions. Accepted $1^{\text {st }}$ May 2019. First published online 30 May 2019.

Sidinei Rocha-de-Oliveira was the associate editor for this article.

Editorial assistant: Luciane Kato Kiwara

Editor-in-chief: Carlo Gabriel Porto Bellini 


\begin{abstract}
This paper aims to contribute to the historical unveiling of a certain set of dispositives and discourses that befell Brazilian textile factory working women who came to reside in the convents inaugurated in the last decades of the $19^{\text {th }}$ century by a textile company located in the state of Minas Gerais, Brazil. By appropriating methodological contributions such as historical document analysis, we present a historically-situated analysis of the discourses and truth effects organized by the company that influenced the lives of these women, along with an articulation of gender issues and the dynamics of power relations. An analytical scheme following the writings of Michel Foucault is proposed, in order to discuss the statements and their truth effects in the factory worker's lives, as well as to create an analytical lens through which the discussion of gender issues can take place. Our findings include the demonstration of how gender can be seen beyond a binary, sexist and biological vision, that is, close to a historical creation of power relations that still involves the female sexed body. Lastly, we also demonstrated how the gendered idea of a female factory worker is strongly built via discourse and performed routinely by the enforced compliance to gendered norms that constrain and constitute a female worker's subjectivity.
\end{abstract}

Keywords: power relations; Foucault; history; gender; organizational studies. 


\section{Introduction}

An extensive body of work regarding women's involvement in the social and productive domains can be readily found in the Organization Studies field, coming from both national (Bruschini, 2007; Cappelle \& Melo, 2010; Carrieri, Diniz, Souza, \& Menezes, 2013; Moraes, 1981; P. M. M. Silva, Rocha, Brito, Barreto \& Gurgel, 2016; Poster, 1979; Thiry-Cherques, 2003; Vieira, Carrieri, Monteiro, \& Roquete, 2017) and international publications (Duffy, Hancock, \& Tyler, 2017; Dwivedi, Joshi, \& Misangyi, 2018; Kanze, Huang, Conley, \& Higgins, 2017; Leslie, Manchester, \& Dahm, 2017; Sangster \& Smith, 2016). Studies on gender, anchored in the most diverse theoretical traditions, provide clues to the broad set of power dispositives and discourses that were (or still are) directed toward sustaining certain regimes of truth regarding women, in general, and Brazilian women, in particular. Among such truths stand out those which have long contributed to the historical justification of discrimination practices towards women, their relegation to the domestic sphere, the denial of their sexuality and their exclusion from or devaluation of their work in the labor market (Cappelle \& Melo, 2010; Moraes, 1981; N. A. Santos, 2016; Rago, 2007).

In this sense, this paper aims to contribute to the historical unveiling of a certain set of dispositives and discourses that befell southeast Brazilian textile factory working women from the end of the 19th century to the first decades of the 20th century. By making room for reflection, not only about the meanings of being a woman but also a factory worker in southeast Brazil at that time, this paper intends to evidence the historical forces behind the legitimization of some of the interdictions and power relations that can still be identified in contemporary Brazilian society.

In regards to its theoretical architecture, this paper intends to place the concept of gender at the heart of power relations (L. C. dos Santos, Carvalho, Amaral, Borges, \& Mayorga, 2016). It is not our intention to argue that the analysis of women's issues from a perspective of power is the only valid one. However, facing the complexity of gender categorization, it is worth noting that by engaging in an analysis based on power relations of such themes we can add to the understanding of a scenario susceptible to changes and interpellations as envisaged by feminism as a social, theoretical and political movement. At the same time, Foucault's concepts of power, discipline and discourse will also be incorporated in this discussion.

Another point worth mentioning is the historical perspective adopted in this paper. According to Barros (2013) and Vizeu (2010), historical research has taken an important place in organizational studies, including the publication of specialized journals such as Management \& Organizational History and Journal of Management History. Authors like Clark and Rowlinson (2004) even indicate a movement of "historic turn" (p. 251) in organizational studies, guided by the adoption of a new set of methodologies and perspectives to approach the past in our field, as organization theorists have increasingly come to agree that "history matters" as a way to understand both ourselves and organizations (Rowlinson, Hassard, \& Decker, 2014, p. 252). 
The inclusion of historical sources, especially documents provided by organizational archives, was once met with reluctance by organization theorists, underutilized and underexplored in their researches (Rowlinson et al., 2014). Now, the repeated calls for more historical researches have been answered, thus leading to the emergence of organizational history as a field located "within the broad universe of organization studies and a constellation of related subfields, particularly business history and management history" (Godfrey, Hassard, O'Connor, Rowlinson, \& Ruef, 2016, p. 591). Defined by the authors "as research and writing combining history and organizational theorizing" (p. 592), organizational history covers a wide spectrum of types of research, ranging from primarily historiographical ones (referred to as history-with-theory), to mainly theoretical ones (theory-with-history) (Godfrey et al., 2016).

On the other hand, authors like Maclean, Harvey and Clegg (2016) refer to this new synthesis between history and organization studies as "historical organization studies", defining it "as organizational research that draws extensively on historical data, methods, and knowledge, embedding organizing and organizations in their sociohistorical context to generate historically informed theoretical narratives attentive to both disciplines" (p. 609). Therefore, no matter how we may call it, it is clear that history has been informing organization studies for a while now, providing data and also assisting in the development of methods that serve as framework to all theoretical approaches that make organization theory, including critical studies (Maclean, Harvey, \& Clegg, 2016).

In order to reflect on what we mean by a set of discourses and dispositives that befell on factory women workers at the end of the 19th century and understand the implications on the remaining discourses surrounding women in the workplace to this day, we are going to take Foucault's (2008) conception of history as a starting point for this paper. The author manages to capture history by its ruptures and discontinuities, rejecting, at the same time, the myth of its enlightening origin and the teleological vision of its promised end. The disorganized dispersions and successions of time and discourse are brought to the foreground, inhabited by concrete subjects in constant dispute, constrained and forced to constitute themselves from the strands of power and knowledge present in their time.

By delving into the archives of the textile company, as well as analyzing excerpts from newspapers and other documentary sources of the time, we seek to provide a contextualized reading of the discourses and dispositives surrounding those women factory workers and what role the organization in question played in it. After all, according to Rowlinson, Hassard and Decker (2014), "understanding the past is central to our historical human condition" (p. 269) and as we understand how organizations played a role in shaping discourses and power dispositives placed on women at the workplace, we also try to offer a viable answer to one of the challenges presented by Godfrey, Hassard, O'Connor, Rowlinson and Ruef (2016) to all organizational theorists: to highlight, via historical research, organizations and businesses involvement in larger social phenomena, as well as specific historical moments.

In addition to this brief introduction, four other sections follow. The next section seeks to synthesize the theoretical framework of this article by establishing a dialog between gender and

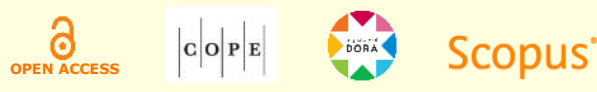


power relations. Next, the methodological aspects are laid out, with an emphasis on the document analysis and the basis of historical documents erected. The following section brings up the analysis, tackling the institution of the convent maintained by the textile company, considering the statements and the disciplinary apparatus present in the everyday lives of these women workers. Finally, the study's contributions and some final considerations are presented.

\section{Gender and its constitutive role}

According to Lewis, Benschop and Simpson (2017) organizational studies show an empirical and theoretical insufficiency when dealing with feminism on a poststructuralist epistemological basis, which remain largely unexplored. In view of this shortcoming, addressing some central concepts of this perspective, such as power, discourse and truth effects, holds a certain promise, given the intention to avoid the risk of portraying a feminism which is uncritical and co-opted by the values of economic neoliberalism.

It is worth mentioning that this articulation between gender and power, like the one that is being proposed here, does have some precedence. It is possible to find other works that have traced similar paths, seeking to establish connections between gender, power, subjectivity and resistance (Cappelle, 2006; Meyer, 1996; Souza, Brewis, \& Rumens, 2016). As an example, Souza, Brewis and Rumens (2016) evidence the criticism of the theoretical presuppositions that define "man as a human being" (Souza et al., 2016, p. 591), with the attribution of a subaltern status to the feminine, and to all characteristics forcibly imposed on the feminine gender as elements resulting from the juxtaposition to male hegemonic standards. According to the authors, "gender does not mean the terms 'woman' or 'man', since it is not an identity or a categorical term but a power apparatus that constitutes these identities and terms as possible and legible" (Souza et al., 2016, p. 606). In this way, the categories of gender not only function as a way of legitimizing and constituting the possibilities of being of the subjects and their modes of existence, but are also seen as the compulsory identification of an anatomical body positioned within a set of rules and reiterated norms, historically constituted by means of exclusions, prohibitions, denials and rejections, as Foucault (1992) points out in his genealogical analysis of power.

In this sense, under the lens of power relations, it is possible to establish another reading of fundamental concepts for feminist theories, such as that of patriarchy, made subject of discussion from the 1970s onwards with the so-called second wave of the Feminist Movement (Boris \& Cesídio, 2007; Delphy, 2009). Thus, feminism traditionally conceives of patriarchy as a social formation, where men were centered at the heart of power, institutionalizing male domination. Under power's perspective, it is possible to re-signify the concept and to understand it in a less static way. Thus, instead of seeing patriarchy as a structure in itself, it is possible to approach it as a discursive construction in the dynamics of power relations (Arruzza, 2015). In other words, the risk of reducing analysis to a logic of structure versus agency or of men versus women is minimized, privileging an analytical perspective of how the discourses of patriarchy are injected into society and are taken by men and women in the power games of their relations.

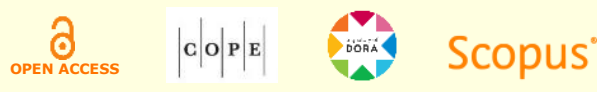


It is possible to establish between Souza et al. (2016) and Scott (1995) a line of dialogue about gender. Scott (1995) not only proposes that the concept of gender be taken as a category of analysis, especially for History, but also proposes a definition of gender to be used. "The essential core of the definition is based on the integral connection between two propositions: gender is a constitutive element of social relations based on the perceived differences between the sexes, and gender is a primary form of giving meaning to power relations" (Scott, 1995, p. 21).

Consequently, Scott's (1995) gender conception is able to conflate the normative symbols and concepts involved in the social construction of gender differences, at the same time emphasizing the political dimension and the exercise of power involved in it. The author argues in favor of the inclusion of a political notion to the historical analysis of gender, which refers to all institutions and social organizations that are part of the construction and normalization of the genders. That is, gender would not only be constructed through kinship, but also through economics, education, and forms of political organization. This leads to the understanding that gender is deeply implicated in the arena of power relations, translated into control and differential access to material and symbolic resources in society.

This discussion is directly related to Butler's (1993) studies, which seek to treat gender as something emerging from the relations of power and resistance, and therefore, as a founding element of human subjectivity. In this way, these dimensions cannot be treated in a dissociated way, since, according to Foucault's (1977) point of view, it is fundamental to understand that power is seen not only in its repressive character, but above all, as a producer of subjectivities. Based on this notion, Butler (1993) makes use of the concept of "gender performativity" (p. 22) to emphasize that, in addition to the subject not possessing an a priori essence, the constitution of their subjectivity is characterized by their involvement in a series of social dynamics regarding control, discipline, regulations and punishments of the self:

Gender performativity is not a matter of choosing which gender one will be today. Performativity is a matter of reiterating or repeating the norms by which one is constituted: it is not a radical fabrication of a gendered self. It is a compulsory repetition of prior and subjectivating norms, ones which cannot be thrown off at will, but which work, animate, and constrain the gendered subject, and which are also the resources from which resistance, subversion, displacement are to be forged (Butler, 1993, p. 22).

By rescuing the concept of gender as a non-natural and non-biological category, Butler (1993) affirms that both masculinity and femininity notions are fictional, socially-created dimensions, in that the roles of both men and women are constituted from a series of regulatory norms and limitations. In this way, constant criticism is made toward the emancipatory effectiveness of this perspective in touching specific demands of women, considering that they are exclusively the raison d'être of the feminist movement. Therefore, even if the subjective constitution of male subjects is also subject to the so-called heterosexual matrix, the hierarchical condition to which male and female genders are generated cannot be disregarded. Nor can the social and political privileges of men and the consequences suffered by women in terms of potentialities, professional opportunities and physical and symbolic violence, be neglected.

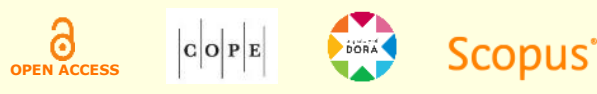


Concerning the dominant heteronormativity in our society, Rubin (2003) emphasizes that both gender and sexuality are the targets of a political struggle entangled in the power webs of society. The author affirms that the category of sex is used to establish a compulsory heterosexuality. As a result, the differences between the sexes are naturalized, men take ownership over reproduction and the production of women, and they also exercise power over them using a contract called marriage (Rubin, 2003).

This is the reason that Butler (1993) points out that "freedom, possibility, agency do not have an abstract or pre-social status, but are always negotiated within the matrix of power" (p. 22). Consequently, what is observed today is that despite the proliferation and repercussions of gender concepts, the female body continues to be subject to a series of power relations that constitute the subjectivity of women, in view of restrictive factors such as the representation of the female image in the media, labor issues related to maternity, as well as the demands and social pressure for femininity that unfolds to attend both the private (housework and care) and the neoliberal model standard of living of a woman who can do everything and who has the right to do everything (Adamson, 2017).

Thus, a gender analysis from the point of view of power relations that is as competent as it claims to be in observing the complexity discussed above, as L. C. dos Santos, Carvalho, Amaral, Borges, and Mayorga (2016) point out, cannot avoid looking at "the situation of oppression and substatus that marks the condition of women in our societies" (p. 592). This observation brings us towards an organizational dimension, represented in this case by the Brazilian textile industry, in order to relate the mechanisms of power to the gender issue, which sought to docilize women for the factory work, thus highlighting their work conditions. That is, the question of discipline also emerges as a central category for the apprehension of the social reality experienced by them.

\section{Power Relations, Discipline and Discourse}

Faced with the extensive intellectual production left by Foucault, some scholars seek to systematize his works in order to establish what would be the different phases of his thinking. Fonseca (2001) points out that, the works of Michel Foucault are usually distributed according to three different methodological emphases, called: Archeology, genealogy and ethics. In this study, we share Araújo's (2008) assumption that is possible to identify a course of maturation that interconnects Foucault's works, in which, from the beginning, is situated the relations of power and their effects of truth. In this sense, we argue, in line with Araújo's (2008) vision, that the genealogical approach did not replace the archaeological approach, as this paper seeks to operate a dialogue between elements addressed by Foucault, both in his archaeological and genealogical phases.

Regarding his conception of power, Foucault (1992) understands power from a relational perspective, as a set of correlations of forces that auto-constitute themselves and produce and organize the domains in which they are present and inserted. Power is a cluster of more or less coordinated, more or less organized, but always unstable, relationships (Foucault, 1992). It is derived from all the points of the social network. That is to say, Foucault believes power is an

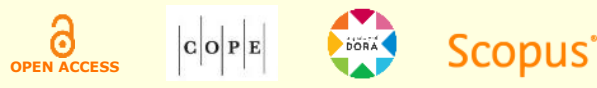


overall matrix of force relations in a society at a specific time. It is, however, noteworthy that the subject is not lost or simply dominated by this set of relations, considering that Foucault states that there are no power relations without resistance. It is also important to point out that Foucault (1977) conceives power under a double negative and positive prism, emphasizing its characteristics of repression versus formation or, still, punitive character versus productive character. After all,

If power were never anything but repressive, if it never did anything but to say no, do you really think one would brought to obey it? What makes power hold good, what makes it accepted, is simply the fact that it doesn't only weigh on us as a force that says no, but that it traverses and produces things, it induces pleasure, forms knowledge, produces discourse (Foucault, 1979, p. 119).

Historically, power gradually became destined for the production of forces and its growth and ordination, much more than its suppression or destruction. That is, power turned into discipline in order to make bodies docile and productive (Foucault, 1977).

The chief function of the disciplinary power is to "train", rather than to select and to levy; or, no doubt, to train in order to levy and select all the more. It does not link forces together in order to reduce them; it seeks to bind them together in such a way as to multiply and use them. ... Discipline "makes" individuals; it is the specific technique of a power that regards individuals both as objects and as instruments of its exercise. It is not a triumphant power, which because of its own excess can pride itself on its omnipotence; it is a modest, suspicious power, which functions as a calculated, but permanent economy (Foucault, 1977, p. 170).

Disciplinary action emerges from the dynamics of power relations that surround the constituent elements of a subject's reality, evidencing the body as an important field of dispute and exercise of disciplinary power. According to Foucault (1977), in our society, power has been relocated to a "political economy of the body" (p. 25). The body, both individual and collective, has come to be the main target of power, necessarily allowing an entire specific knowledge about the body to flourish, so power can act upon it. However, it is not merely a type of knowledge inclined towards the anatomy or physiology of bodies, but rather a set of techniques that make it possible to control and docilize it (make it compliant), making it useful (Foucault, 1977). It is this knowledge or political technology of the body that is used to make bodies and desires submit, without simply having to resort to the excessive use of force or violence; rather, one derives one's modus operandi from a long list of diffuse, discrete, anonymous and subtle dispositives and procedures.

... the body is also directly involved in a political field; power relations have an immediate hold upon it; they invest it, mark it, train it, torture it, force it to carry out tasks, to perform ceremonies, to emit signs. This political investment of the body is bound up, in accordance with complex reciprocal relations, with its economic use; it is largely as a force of production that the body is invested with relations of power and domination; but, on the other hand, its constitution as labour power is possible only if it is caught up in a system of subjection ...; the

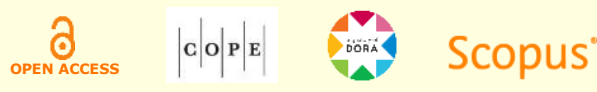


body becomes a useful force only if it is both a productive body and a subjected body (Foucault, 1977, pp. 25-26).

Another important point of the exercise of disciplinary power concerns the definition of space and its functioning norms where bodies can be placed in a set of differences, in which they are compared to each other and also in relation to the rules adopted as standards of reference. Delimitation of the spaces is established following a principle of the enclosure, elementary location or partitioning: fixing each individual in its own place and in each place an individual. Thus, disciplinary space is partitioned into as many sections as there are bodies to be distributed, seeking to eliminate the risks and dangers that could arise from the agglomeration of the subjects and the loss of the usefulness of the bodies by the absence of an effective control (Foucault, 1977).

If we take the factories as a form of production of spaces, it is important to emphasize that, in addition to the partitioning process, several techniques are articulated in order to control schedules, such as the atomization of acts, calculation of movements, hierarchical vigilance, and finally, the search for the exact adjustment between bodies and machines, as praised by the Taylorist canons so dear to mainstream management. Also, by drawing a connection between gender and power it is possible to create a lens capable of showing how certain disciplinary spaces have been historically organized in order to shape and justify the submission of the feminine, as an encompassing category, to the masculine, and, as a result, of women to men.

In this sense, discipline and the knowledge that accompanies it emerge, par excellence, from the technology of docilization of the bodies, disseminated by the most diverse institutions and internalized by individuals, even at the physiological level. That is to say, the subjects have their bodies disciplined in countless spaces and institutions they encounter, beginning in early childhood. After all, it doesn't matter whether we are talking about schools or factories, which can be found in both is a refined disciplinary system in operation.

In his other works, Foucault (2009) discusses various modalities of the exercise of power, clarifying how it runs its course and metamorphoses, adjusting to the specific mechanisms of each institution and the different interests by which it is invested. Among the modalities discussed by Foucault we have the pastoral power, which is closely related to the discourse of salvation, allowing individuals to constitute themselves and advance in their existential search to selfimprovement. Religious ethics are able to provide substance and meaning so that individuals may develop their techniques themselves, which differentiate and place them in the world. By Foucault's accounts,

The pastorate is connected to salvation, since its essential, fundamental objective is leading individuals, or at any rate, allowing individuals to advance and progress on the path of salvation. This is true both for individuals and for the community. The pastorate therefore guides individuals and the community on the way to salvation. Second, the pastorate is connected to the law, since for individuals and communities to earn their salvation, it must make sure that they really submit to the order, command, or will of God. Finally, third, the pastorate is connected to the truth, since in Christianity, as in all scriptural religions, earning

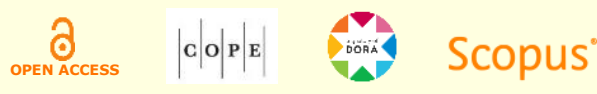


one's salvation and submission to the law are, of course, conditional upon acceptance, belief, and profession of a particular truth. So, there is a connection to salvation, the law, and to truth; the pastor guides to salvation, prescribes the law, and teaches the truth (2009, p. 224).

Finally, it is interesting to delineate the correlation between discourse and power in Foucault's thinking, seeing as the crystallized discourses found in the documents serve as a starting point in order to carry out the intended analysis. Fairclough (1992) argues that one of the side effects of Foucault's genealogy on his archeology was to insert the issue of power, underlining its circular relationship with what he calls regimes of truth. Thus, in the author's opinion, Foucault's theoretical shift to genealogy represents a decentering of discourse in his work, raising the question of power systems to the foreground of analysis. However, discourse and language still remain at the heart of social practices and processes (Fairclough, 1992). In the following passage, Foucault (1992) makes very clear the correlation between discourse, power and truth:

What are the rules of right that power implements to produce discourses of truth? Or: What type of power is it that is capable of producing discourses of power that have, in a society like ours, such powerful effects? What I mean is this: In a society such as ours-or in any society, come to that-multiple relations of power traverse, characterize, and constitute the social body; they are indissociable from a discourse of truth, and they can neither be established nor function unless a true discourse is produced, accumulated, put into circulation, and set to work. Power cannot be exercised unless a certain economy of discourses of truth functions in, on the basis of, and thanks to, that power. ... let us say that we are obliged to produce the truth by the power that demands truth and needs it in order to function: we are forced to tell the truth, we are constrained, we are condemned to admit the truth or to discover it. ... We have to produce the truth in the same way, really, that we have to produce wealth, and we have to produce the truth in order to be able to produce wealth. In a different sense, we are also subject to the truth in the sense that truth lays down the law: it is the discourse of truth that decides, at least in part; it conveys and propels truth-effects. After all, we are judged, condemned, forced to perform tasks, and destined to live and die in certain way's by discourses that are true, and which bring with them specific power-effects (Foucault, 2003, pp. 24-25).

\section{Methodological Aspects}

This paper follows a qualitative approach (Rey, 2005), which understands knowledge as a human production, marked by its constructive-interpretative character, thus rejecting the idea of a linear appropriation of social reality by the researcher. As for the methodological approach, we opted for the historical method of document analysis (Bowen, 2009). It is common to consider this form of analysis as a complement for other research methods in the qualitative research approach. However, in accordance to Bowen (2009), in many cases, the document analysis has been used as a stand-alone method. Bearing witness to past events, documents can provide background information and valuable historical insight, which can help researchers understand and better address the historical roots of specific questions, as well as indicate the conditions that affect the phenomena currently under investigation (Bowen, 2009). Additionally, it is known that documents may be the most effective means of gathering data of past events that can no longer
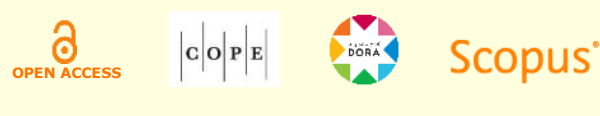
be observed or accounted for, or when those qualified as informants are no longer capable of recalling the complexity and detail of the historical context addressed.

Understandably, documents may be the only necessary data source for studies designed within an interpretive paradigm, as in hermeneutic inquiry; or it may simply be the only viable source, as in historical and crosscultural research. In other types of research, the investigator should guard against over-reliance on documents (Bowen, 2009, p. 29).

Although documents are considered a rich source of data, according to Bowen (2009), it is advisable that researchers look at them with a critical eye and become cautious in using documents in their studies. Documents, advises Bowen (2009), should not be seen as precise, accurate or even complete accounts of past events. Rather, researchers should look at the documents' meaning and contribution to the issues being explored. In this sense, by articulating a methodological construction supported by elements of a Foucauldian genealogy and archeology, this paper seeks to establish relations between the repertoire of statements evoked by the subjects and the set of institutions, rules, values and regimes of truth present in context. What is important is to highlight the existence of these statements and knowledges that anchor and support the truth status emanating from the discursive practices of the subjects. That is, this paper seeks to historically situate the subjects' discourse in relation to their degree of proximity to the set of discursive formations presented and perceived as true in their sociohistorical context.

In this respect, this paper analyzes the convent, a structure owned by a traditional textile company in the state of Minas Gerais, Brazil, whose first plant was inaugurated in the last decades of the $19^{\text {th }}$ century. The company has been in operation for more than 140 years, intertwining its trajectory with various Brazilian historical landmarks, and its leaders, generation after generation, were faced with the respective contingencies of their time. It also continues to be a reference in the national scenario, both in terms of volume and the recognized quality of its products. Consequently, in order to preserve the confidentiality of the company and its subjects, the generic and fictitious name Textile Company was adopted, which will henceforth be used to designate it.

All data collection was conducted in the documental archive preserved by the company, located in the courtyard of one of its first factories, in upstate Minas Gerais, Brazil. It is important to point out that the factory houses a collection composed of several pieces from the time of its foundation such as ox carts, old looms, huge machinery, industrial instruments and fabric samples, and yet, the documents collection is not open to the public. In order to carry out this research, it was necessary to obtain the formal authorization of the company to access the records used here, which minimized, at least in part, the risk of accessing only public documents preselected by the company and which would be mainly limited to the narratives of its official history.

As follows, the research corpus was made up of all the reports, minutes, daybooks, contracts, newspaper clippings, statements, memos, inventory and payroll records, point controls, employee records and countless sent and received written correspondence by the founders, managers, shareholders and workers of the Textile Co., dated from the year 1887 to 1934 . The collection is divided into two large groups: Received Correspondence Box and the Bookshelves. The first

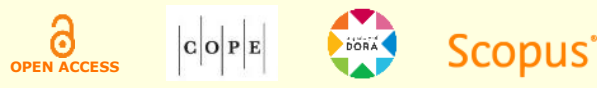


group consists of 957 boxes filled with a variable number of documents, from tens to hundreds, divided by themes and dates. The second set is represented by about 163 books where the most varied aspects of the organizational routine were recorded. Among them are the draft books, daily books, accounting books and letter-copying books, in which can be found the letters that were exchanged between managers, owners and employees of Textile Co. almost daily.

It is important to note that, working as a secondary database for this study, some other published works also sought to take the Textile Co. as a research object and utilized the documents preserved in the company's collection. Among them, it is worth mentioning Domingos Giroletti's book (1991), which discussed the formation of factory workers as a work force, from the last decades of the $19^{\text {th }}$ century to the present day; and the work of Junia de Souza Lima (2009) that focused on analyzing the process of insertion and training of female labor in the textile industry from 1872 to 1930 . It was necessary to employ such works as a secondary source since changes were identified in the cataloging and displaying of various folders and documents preserved in the company's collection, which made it impossible to find some of the documents cited by the authors in question. Furthermore, intertextual relations have been established with contributions of different fields of knowledge. Thus, whenever necessary, the analysis will oscillate between statements of leaders and workers and the statements of other institutions or legitimated by different areas of knowledge.

Regarding the analysis, we opted for the construction of two thematic axes. The first was comprised of the disciplinary mechanisms operating at the intersection between the convent and the factory. On the other hand, the second axis shed light on the practices and discourses operating at the formation of the subjectivities and constitution of women workers, seeking reverberations of the power relations there present in other apparatuses and institutions that bordered the convent and the factory. Therefore, it is important to emphasize that this work does not seek to exhaust the discussion about all the statements present in the long history of the company studied and even less, to support a final or official version of Textile Co.'s history. We sought to multiply relationships and foster reflections about the social and labor context of these workers, nothing else.

\section{Convents and the disciplinary dispositive}

Before delving into the lives of women workers at the factory's living quarters and the statements making up their existence, it is important to notice the historical context in which they were living. According to Sardenberg (1997), the history of the rise of industry in Brazil begins with the establishment of the first cotton mills, emerging around mid-1800s and relying mostly on a female labor force. As stated by Carrieri, Diniz, Souza and Menezes (2013), in the early $19^{\text {th }}$ century, women were considered part of cheap and qualified labor and their presence was most common in the weaving and wiring factories, sharing space with their male counterparts in the job market. Sardenberg (1997) further comments that "because of their subordinate position in the family - and their supposed 'natural' docility - women have been preferred over men as they were expected to conform more readily to the process of 'domestication' of the worker to the factory system" (p. 360).
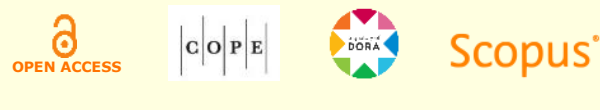
Margareth Rago (2007) cites data collected by historians which shows that by the end of the $19^{\text {th }}$ century women and children made up close to $72.24 \%$ of the labor force working at the wiring and weaving factories located in the state of São Paulo. Nevertheless, the patriarchal division of labor within the mill dictated that the chain of command was mostly composed of white, male and older individuals. As a rule, white men occupied all the supervising positions, especially those of mestre (overseer), and contramestre (assistant), which made them known to be ruthless with their subordinates and, not rarely, sexually harass them (Sardenberg, 1997). Giroletti's (1991) account of this textile company's hiring practices in Minas Gerais follows the same tendency, by exploring how the factory management often prioritized women and children, among other socially outcast individuals as their primary labor source during the first decades of the factory's operation, mostly due to its cheap value. Hiring women, especially unmarried, young, poor women in the northern region of Minas Gerais, a severely underdeveloped region at the time according to Giroletti (1991), required a few specific practices that will be addressed in this section.

Around the perimeter of their first factories, Textile Co. maintained a peculiar institution known as Convent, with a housing capacity of 60 girls, according to $\mathrm{Vaz}$ (2005), who also indicates the year of 1882 as the beginning of its operation and the year of 1886 as the official inauguration. Giroletti (1991), on the other hand, explains how the company convents existed until the 1920s, indicating the year of 1926 as the most likely of their closing. Despite the strong religious connotation openly flaunted by its name, the Convent was born of the factory's need to recruit and to train its workers. Essentially, the convent of Textile Co. plant was an exclusively female boarding facility, erected with the goal of receiving poor girls, orphans or widows interested in employing their productive forces in the service of the factory. It represented a double cost saving for the company, for it eliminated the need to build new homes for whole families of workers and, at the same time, privileged the hiring of young women that were paid even less than the other workers. The inner workings of the Convent are better described by the manager of Textile Co. in a letter dated to August 18, 1889.

The factory maintains a "Convent", where working girls are gathered. They are governed by a lady with excellent qualities and strong confidence, under whose watch girls live a satisfying life, in community with each other, walking, going to the Catholic Mass in the camp nearby; have a doctor and pharmacy provided by the factory, and are only in need of food and clothing: the cost of food becomes modest for each, since it is shared among all in just one little house; thus, the higher the number, the more favorable it becomes for each in terms of cost (Textile Co., personal communication, Book of Letters, 1888/1889, fl. 419, Museum Collection).

At first glance, the Convent appears to be just an accommodation for girls provided by the factory. However, in terms of discipline (Foucault, 1977), it constituted a structure of semi-reclusion, guaranteeing full company control of the workers, who lived in a regimented routine. In this sense, space itself emerges as part of a disciplinary dispositive (Foucault, 1977) par excellence, allowing, as we shall see, privileged control over bodies in their docilization process.

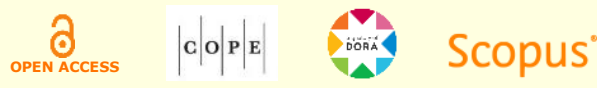


One of the main control techniques was represented by the figure of the abbess, usually played by a widow who managed the Convent, supervised and monitored the conduct of the girls, governed by a strict moral code. For the office of the abbess, poor women were also recruited, because the payment offered was not usually high. The profile sought pointed to religious ladies with unblemished posture, endowed with a reasonable degree of instruction, charismatic enough to keep the girls satisfied and, at the same time, serious and wielding sufficient authority to make sure that order and respect were maintained. The isolation required of the women in there compared to the rest of the inhabitants of the workers' village, in particular of men, was sought at all costs, even if it was necessary to separate them from the conviviality of their relatives, as portrayed by the excerpt below.

The abbess selected is good. ... I let her know that you did not want the boy there, so they would not have any excuse to visit the mother and the girls in the Convent; she's willing to part from him if you give him a job. He's a serious boy and incapable of any bad deed. Good family. ... I didn't discuss price with the abbess. They're people of good breeding and very poor, and are happy themselves with anything fair and reasonable. Arrange to fetch them ... (Textile Co., personal communication, Received Correspondence Box, 1898, box 10a).

The privileged traits for the choice of the abbess highlight some elements that will emerge as important in the disciplinary exercise to be performed, besides the aspects symbolically shared around the standard conformed for the female gender (Butler, 1993; Scott, 1995). Amongst them, the appreciation for her religious affiliation, which would allow her to recall the ethos of religious discourses, which refers to the appeal of pastoral power (Foucault, 2009), in her task of monitoring, moralizing and disciplining the conduct of women in the Convent. On the other hand, it is also possible to identify the gender performativity (Butler, 1993) made explicit by the reiteration and repetition of gender-conforming aspects, such as the maternal role, which is inferred from the charismatic profile of the abbess drawn by the documents. Moreover, it is interesting to note that the prism of power reveals that norms and discourses about control and submission of women circulate and are appropriated by different subjects, and that women themselves may, like the abbess, perform the function of reinforcement and naturalization (Scott, 1995) of these regimes of truth.

The workers' routine in the Convent was limited by a closed perimeter of movement, permanently guarded, punctuated by the comings and goings in confined spaces of production, training and rest - that is, the factory, the school and the Convent itself. The discipline's rigidity and the timetables kept by the young women resembled a regime found at the religious institutions from which its name had been borrowed. The daily lives of the Convent dwellers adjusted perfectly to the routine of the factory.

They got up at five in the morning, saw to their personal hygiene, made their beds, prayed and went to the canteen, where they took their first meal and went to work. They would leave the convent by a side door and climb down the ladder, and they were inside the factory yard. They would return by the same route in the intervals established for eating, returning, then, to their jobs at the plant. At dusk, returning home, they washed, prayed the rosary and, at 8:30, went

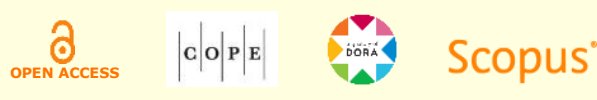


to sleep. Those who frequented the school were in class from 7 to $8: 30 \mathrm{p} . \mathrm{m}$. Their comings and goings were controlled by the abbess, by internal colleagues or by guards or heads of discipline. The return, a little later, was particularly guarded, because it was one of the occasions on which the girls were trying to escape with their boyfriends or were abducted by Romeos in love with them. At other times, the girls avoided the supervision of the abbess, jumping the wall of the convent for their amorous adventures with their delighted princes (Giroletti, 1991, p. 179).

The previous quote indicated, although timidly, that regardless of the strict control over the workers, there had always been practices of resistance, such as romantic escapades or quick breaks through the iron curtain around the Convent. However, the disciplinary dispositives used to monitor and control the dwellers of the building were not limited to rules and regulations, but also spanned the spatial arrangements of the Convent. Reformation undertaken in 1887 proves this feature, making, as it did, the abbess's room the only way for all the girls to enter or leave their dorm. Thus, each movement was monitored, as indicated by the excerpt.

I organized the new convent, for which I opened the old convent in just one bedroom, occupying the visiting room, dining room, infirmary, pantry and housekeeper's room, through which all the girls will pass to get to the dorm - which can hold 60 beds (Textile Co., personal communication, letter signed by the manager of the factory, dated October 15, 1887, Received Correspondence Box, 1887).

In the previous sections, it is also clearly evident the use of the previously mentioned "partitioning technique”, discussed by Foucault (1977, p. 143), in this case generating a map of space-time coordinates, able to determine for each hour of the day, the exact locations and the tasks of each convent worker inside and outside the factory within the cycle of continuous production-trainingrest-production.

It is important to note that, within the factories, a rigid moral and disciplinary code also prevailed, allowing the refinement of disciplinary procedures and making visible a set of micro penalties. That is, it became possible to penalize even the slightest and weakest deviations of conduct, accentuating the formative character of the discipline over bodies (Foucault, 1977).

To Mrs. Debrandina Almeida dos Santos, we applied the disciplinary suspension penalty, with loss of salaries, as of this date, for a period of 11 days, due to lack of respect with her boss (Textile Co., personal communication, document signed by the Manager of the Factory on December 12, 1953).

There is a worker here, the daughter of a family of Montes Claros, who is a daring and mischievous girl, and who does not want to submit to order or to anyone in the factory. She left the loom without notifying anyone, and the mother, who has three daughters, wants to send her to the Convent. ... I urge you to be even more punctual in this regard with the request of this insubordinate maid and do not accept her there so that she becomes a bad example

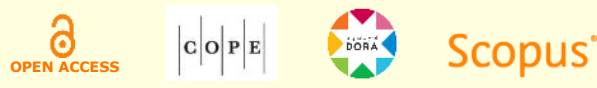


(Textile Co., personal communication, letter from the manager to the superintendent of Textile Co., 1891, Received Correspondence Box, box 11A).

In the previous excerpts, the value placed in the disciplinary example is clear in both cases of failures committed during the working day inside the factory. However, other types of slips committed just outside the work environment were also punishable with the maximum expulsion penalty. Among them, it is possible to highlight deviations of conduct or attacks on morality, clearly demonstrating the role of leaders in curtailing the sexuality of their workers.

The main reason for this letter is to inform you that due to the dyer's incorrect behavior ..., which sought to seduce a maid in this place, a young lady of the family, which was automatically proved by a letter written by the man's own fists to the same young lady, I dispatched him today from this establishment ... This dyer is a most ordinary scoundrel, who seduced and had a naive young girl kidnapped; and for example and morality of the place I will prosecute him, signing as part of the (judicial) process (Textile Co., personal communication, letter signed by the plant manager, dated August 30, 1900, Received Correspondence Box, box 30A).

... At last the girls' thief was discovered; the dyer, they say, is involved in this story; one of the girls was from the convent. The abbess says that she slipped away when the girls were leaving the night school (Textile Co., personal communication, letter signed by the manager, February 2, 1900, Received Correspondence Box, box 30A).

In the excerpts cited above, attention is drawn to the objectification (Adamson, 2017; L. C. dos Santos et al., 2016) of women, considering the responsibility for the escape or the abduction, even if consented, of the convent girl, is only imputed to the man. Besides that, in line with the views of Rubin (2003), Delphy (2009) and Boris and Cesídio (2007), it is possible to identify not only the dominance of a heterocentric matrix, but also the presence of a patriarchic discourse via the imposition of marriage as the only legitimate way for women to access sexuality.

If we were to analyze the disciplinary regime implemented at Textile Co. exclusively from its repressive or negative bias, it would mean to neglect another fundamental dimension of power: the production of meaning. The individual is constituted through relations of power. And it is through power that their rituals and regimes of truth are built and sustained, for, as Foucault (1977) insists, power produces reality.

In the nine years that the Mrs. has worked here, has always developed an activity of dedication so out of the ordinary that it has rarely been any companion able to match it. If your work has been profitable to us, your example has been even more advantageous us. It is, therefore, our duty, today, on the day of your marriage, to express to you how grateful we are to you, asking you to accept the little stipend we offer you (Textile Co., personal communication, letter sent to a laborer dated February 5, 1881, Copied Book of Letters of the Textile Co. from 1881 to 1883, p. 486).

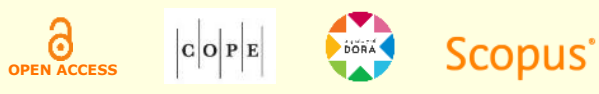


As evidenced by this excerpt, the producing facet of meaning is present at the heart of power relations (Foucault, 1977). Thus, by working in an exemplary way, the employee would be compliant with some sort of supreme law of humanity, achieving a unique status before the body of workers and becoming worthy of the recognition and gratification received. That is to say, starting from an exalting speech of the example of dedication of the worker, a game of differences is set into motion that differentiates between the hard worker and the lazy worker, virtue and indolence. Bad example, punished; good example, exalted.

\section{Performing and constituting gender}

Moving on to the analysis of gender constitution (Butler, 1993; Souza et al., 2016) and their effects on the daily lives of workers, it is necessary to shift our focus to the condition of women and the statements regarding their submission. Used as the object of different discourses and target of the truth schemes of various institutions, the term woman is the bearer of the historicity that is proper to it, where a whole set of fundamental problems for the context being studied is able to emerge. In order to approach the main question about the workers who inhabited Textile Co.'s convents, it is important to remember that we are talking about poor women, for the most part without means of support, who lived in the late $19^{\text {th }}$ century in the hinterlands of the province of Minas Gerais. We are speaking of women practically left without alternatives, surrounded by a "an ethics for men: an ethics thought, written, and taught by men, and addressed to men - to free men, obviously" (Foucault, 1990, p. 22). Women who were fighting for their survival in a world governed by men and constructed by the male point of view, in which the place reserved to them was always at the margin or "in which women figured only as objects or, at most, as partners that one had best train, educate, and watch over when one had them under one's power, but stay away from when they were under the power of someone else (father, husband, tutor)" (Foucault, 1990, p. 22). The role of this other was fully assumed by the managers of the company, who took upon themselves the burden of the protection offered to, the moral education given to and the labor extracted of these women who would become the responsibility of their husbands only after married.

Regarding the admission in this establishment of the family you have mentioned to me, I cannot grant it due to the absolute lack of rooms and because there are no personnel openings at the factory. Today I am in need of people, and I still have no room, so I can admit only the five girls who make their expenditures in common, receiving each one the balance in her favor. These girls are under the direction of a distinguished lady and under the immediate responsibility of the mill manager (Textile Co., personal communication, letter from the manager of Textile Co, dated May 15, 1889, Copied Book of Letters, 1888/1890, p. 187).

We start the examination of the statements that deal with women's submission with the discourses socially disseminated in the region of Textile Co. by the media outlets of the time, which had at their core a clear conception of the societal role of women. This trajectory is essential to better understand the social context in which the women workers of Textile Co. lived until the first decades of the $20^{\text {th }}$ century.

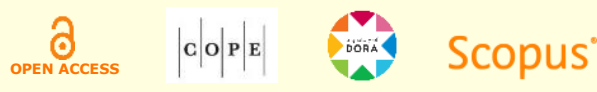


A father who knew through a lifetime of experience the value of a household and of a woman who was not a mere object of luxury; wanting to marry off his daughter, announced that he would give the man a dowry of 20 Contos de Réis ${ }^{1}$. Suitors soon appeared. Having gathered the information, the father's choice settled upon a young businessman. On the eve of the marriage, he called his future son-in-law to the office and said to him: - My dear son, I give you the dowry of thy wife. And taking a paper from his pocket, read: DOWRY OF MY DAUGHTER. A painstaking education. Music. Knows 2 languages. A very frank, just and proper spirit. All of this is well worth $\$ 1,000$. My daughter is not a "survey". This quality by itself is worth no less than $\$ 4,000$. Is accustomed to order and to economy. She knows how to direct a family and has all the qualities of a perfect housewife. She has learned to cook and prepares excellent dishes. This is worth $\$ 6,000$. She has no enthusiasm for running the circuit of shops, is not crazy about dances or shows, and above all loves her home. Value: $\$ 2,000$. Has very good hands. She is very active and in case of need could sew her own dresses and hats. This is worth $\$ 2,000$. I give you $\$ 2,000,000$ in cash and in your hands these two contos de réis are a veritable fortune, because she is work, frugality and providence in person, $\$ 2,000$. Total: $\$ 20,000,000$. The youth paled to hear the reading, but, although with some reluctance, married the girl. Some years later, after embracing his wife, he said to her: "you have been my happiness!". He recognized then that the science of household management is the first quality of a woman, the first thing that should be sought in her, as the only one who can save our homes. "Se non è vero è ben trovato..." (Even if it's not true, it makes a good story) (The dowry of a girl without dowry, 1922, our translation).

The enunciative function (Foucault, 2008) of the newspaper article, dated May 1922, indicates the construction of an ideal model of woman, raised and educated to become a resigned and dedicated housewife. Putting the household and the domestic economy as the woman's exclusive domains highlights the notion of submission to the husband and the search for legitimation of a patriarchal nuclear family model, one that sees the man as the breadwinner of the house and the authority of the family, in accordance with the model socially imposed on women as denounced by authors like L. C. dos Santos et al. (2016), Moraes (1981) and Poster (1979). Thus, work outside home was only tolerated for unmarried women. Such assertion can be checked in letters signed by the managers of Textile Co., where one reads: "To be admitted as a worker you must meet the following conditions: ... as a woman you have to be single. Married women are not accepted" (Textile Co., personal communication, 1916-1917, pp. 131-140). This guideline is also corroborated by Lima (2009) in her comprehensive study of the gender question at Textile Co. The author carried out a survey on the civil status of workers recorded in the books of the factory, evidencing that the posts occupied by married women accounted for rare exceptions, because "among the 213 workers that joined the factory between the last decade of the $19^{\text {th }}$ century and the first two decades of the $20^{\text {th }}$ century, 5 of them were married, 2 were widows and the others were unmarried" (Lima, 2009, p. 112).

Furthermore, the following picturesque anecdote serves as an illustration that the discourse of objectification and commercialization of women, in which even the choice of the bridegroom is presented as a prerogative of the father, legitimates the primacy of the authority of a man over the free will of a woman. It is possible to establish a clear parallel between the previous section

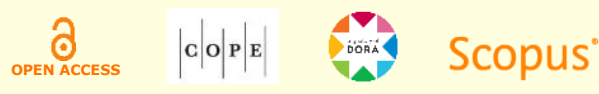


analyzed and a classic text titled The traffic in women: Notes on the 'political economy' of sex, where Rubin (1990) critically discusses the practice of women's exchange in the historical formation of kinship and cultural systems, in which women constitute a mere commodity to be traded and exchanged among men. In addition, a curious mathematics of womanly virtue is put into operation. Based on calculation, note that the pricing openly flaunted establishes a game of differences among the supposed qualities of the object woman. Our attention is called to the fact that the most devalued attributes in this equation (earning the minimum sum of one conto de réis) are erudition (painstaking education and speaking two languages) and the traits of a woman (frankness and uprightness).

On the other hand, the immaculate reputation of the lady in the region, by itself, would be priced $400 \%$ higher than the previous attributes. It is no surprise that the attributes most valued in this masculine mercantilist ethics would be those contributing to the making of a perfect housewife, reaching the highest value of the list, set at six contos de réis. What it reveals is a complex social hierarchy of female qualities, built under the dominant male bias. Such virtues converge on the articulation of a dense system of truths, which was used to guide the preparation of women, justifying their submission and transforming them into people skilled in the science of household management, in a tangled process of constitution and performativity of gender (Butler, 1993; Souza et al., 2016).

The social conduct of a woman and the curtailing of her libidinal impulses constituted other relevant concerns portrayed in the newspapers of the time.

To the boys

A practitioner of the world and even more of skirts... with Eves within, wrote: - that for the general tranquility, a woman should only leave the house three times: the first, to be baptized; the second, to marry; and the third... to go to sleep at the cemetery! ... - Today everything has changed. Nowadays, girls think to themselves, - if one boyfriend is good, two is excellent, and three is even better!... Progress or demoralization? Choose your terms at will and put them into place as you wish. Going out with somebody - that dry fishing that results in nothing only serves to decrease sincere love and do away with the sacred institution called marriage. ... Therefore, - inexperienced young men -, when you burn in a flame of loyal passion and see that the beloved object is sharing what should be only for you, have energy, courage and strength of will... flee, run away, disappear, never to return, though you take despair into your soul and your heart in pieces, to bleed with pain. To prevent the boat from turning, it is good to jump ashore ... (Areimor, 1916, our translation).

In the article quoted above, which circulated at a workers' settlement in 1916, the censorship displayed toward coquettish traits in women is accompanied by a complete silence about any mutual calling to account of the conduct of men. On the contrary, they are advised to abandon or depart from their partners at the first sign of deviations in their behavior. It is clear that this is not a field of signification reciprocally designed for both genders (Butler, 1993; Scott, 1995). It does not for a moment seek to draw up symmetrical conduct required of both. What one notes

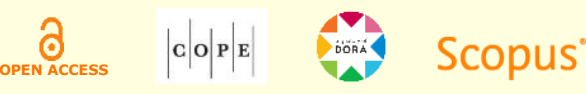


is the clear-cut presentation of a discourse of men and for men, concerning the training and control of women. This vision is reinforced by the very title of the article, which is addressed to boys, or inexperienced men, and not to women, despite the fact that, essentially, its purpose is the criticism of the latter's conduct. Thus, what is observed is the production of effects of asymmetric truth from the same discourse (Foucault, 2008), prescribing to men the task of monitoring and, in parallel, prescribing to women a standard of morality to follow.

Another point that draws our attention in the article in question is the strategy of legitimation used by the author of the article to bring to the discourse two traditional instances of authority. Thus, the author appeals to figures of government and religion to endorse the truth value (Foucault, 2008) of his arguments, giving them the place of the subject in the assertion that deals with the statutory validity of monogamous marriage (Rubin, 2003). In addition, the force of the patriarchal discourse is explicit (Delphy, 2009) in which the aura of religion rests on the institution of marriage, making it sacrosanct, while the woman is constantly treated as an object and the property of her husband (Moraes, 1981; Poster, 1979). Religious knowledge represents a source of truth par excellence. Its influence has repercussions not just for the work logic, as it is also possible to isolate statements that deal directly with the idea of women's submission or that reinforce the myth of the weaker sex (Moraes, 1981; Scott, 1995).

It is important to turn to the analysis of religious discourse as it is certainly relevant in the case in question, once we notice how the strength of religiosity and the authority of Catholic institutions in the Textile Co. region extended over all the workers, especially affecting the women living at the Convent. The excerpt below demonstrates that the Convent was also a place marked by the pastoral power (Foucault, 2009) of the Church, which hosted religious celebrations for the factory workers periodically in its chapel.

What best characterizes the facility for female workers was the name, Convent. In fact, almost all the women were virgins, as far as I can see now. There was a convent chapel, with windowpanes of various colors, disturbing the daylight. The presence of the images and the altered light maintained there a strange environment, which inculcated respect. I never entered the chapel to run. My aunt was the abbess, they said. Only now I perceive the irony: because the house definitively started to be called the convent (J. B. Silva, 1934, p. 24).

We observe the articulation in place between the factory and the Church goes much further, culminating in an arrangement of mutual reinforcement, able to promote social standards that were of interest for both institutions. The model of the nuclear monogamous family (Delphy, 2009; Moraes, 1981; Poster, 1979; Rubin, 1990) the importance placed on obedience and discipline, the suppression of libidinal impulses (Rubin, 2003) and the defense of the precepts of morality are examples of issues jointly and severally worked on and reinforced by the discourse of the priests and managers.

Legal knowledge represents another important discourse present in the field of adjacency of the statement on women's submission. In Brazil, the Civil Code of 1916 was based on the old Filipino Code of 1870 and clearly delimited the relations of power between genders, legally

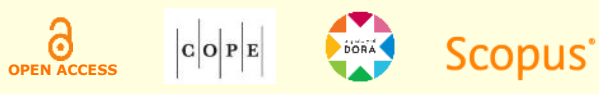


conferring upon the husband the designation of head of the family. Legal knowledge recognized and legalized the supremacy of men over women, limiting women's access to employment and to property. Married women were also legally prevented from becoming heads of their families, except in the absence of the husband. So far, it has been possible to see that the process of building, sustaining and disseminating the elements that shaped the feminine ideal in our societies (Butler, 1993) is articulated not only to cultural customs and practices, but also to the production of discourses of truth (Foucault, 2008), even within the scope of the effectiveness of the law, which insert the question of gender undoubtedly in the arena of power relations, as advocated by authors such as Lewis et al. (2017), Arruzza (2015), Cappelle (2006), Scott (1995) and Meyer (1996).

Art. 6. Incapable in relation to certain acts (Art. 147, n. 1), or in the manner of exercising them are:

I. Those over sixteen and under twenty-one years of age (Art. 154 to 156).

II. Married women, as long as the conjugal society continues.

III. Spendthrifts. ...

Art. 233. The husband is the head of the conjugal society. It falls to him:

I. Legal representation of the family.

II. The administration of common goods and those of the property of the woman, which the husband is competent to administer, by virtue of the adapted matrimonial regime, or of the ante-nuptial agreement (Art. 178, § 9, no. I, c, 274, 289, no. I, and 311).

III. The right to fix and change the domicile of the family (Art. 46 and 233, no. IV)....

IV. The right to authorize the profession of the wife and her residence outside the conjugal roof (Art. 231, no. II; 242, no. VII; 243 to 245, no. II; and 247, no. III).

V. Provide for the maintenance of the family, respecting the provisions of Art. 277....

Art. 242. The woman may not, without the authorization of the husband (Art. 251),...

IV. Accept or reject an inheritance or legacy. ...

VII. Exercise a profession (Art. 233, no. IV)....

Art. 380. During the marriage, the husband exercises the family authority, as head of the family (Art. 233), and, in his absence or inability, the woman.

(Lei n. 3.071, 1916, our translation).

Imposing the condition of an object upon the women, this kind of knowledge generates discourse that influences and reverberates on vast areas of social life. The superiority granted to men over women was not limited to the legal context but extended to various other aspects of social life as well, being found even in the arbitration of disputes, in that, clearly, the testimony of one or the other were treated differently. This can be seen in the letter quoted below, dealing with the rape accusation placed by a worker in 1889 against Mr. James, an English mechanic, who at the time occupied the office of General Factory Master. In it, the plant manager is forced to judge the case based on both accounts, initially accepting as truthful the version of Mr. James to the detriment of the simpleton worker supposedly assaulted. Possibly, the factory's dependence on the foreign mechanic's workforce could have counted more than the gender question involved in the strife. However, the most important thing is to highlight the unequal power relations (Foucault, 1977) established between a woman worker and the General Master of the company.

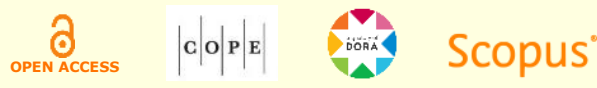


In relation to my reserved testimony on February 14, I have to tell you that, although all suspicions of wrongdoing to the simpleton worker fall on Mr. James, one cannot affirm that he is the perpetrator and if the foolish woman was raped in actuality. However, I just had a talk with Mr. James and I told him that if his conscience accuses him of something, that it is a question of his family, and then of his country, considering that the crime would be great, and great misfortune would fall upon his family. He denies the crime of which he is accused and says he has a clear conscience. I had the idea of sending a doctor to examine the supposedly offended party but decided not to because the exam would take on a judicial character. Appeal for the future. Every step that I took was combined with the views of [the owners]; the latter was of the opinion that James should be cleared, and I prefer to free 10 criminals rather than to condemn an innocent man, considering that nobody is free of an imputation like this. For while everything is as it is, the future will discover the truth (Textile Co., personal communication, letter signed by the manager of Textile Co., dated February 17, 1889, box 11A).

After carrying out the entire ritual of truth that the situation required, the General Master was found guilty and he was dismissed from the company, immediately after the decision of the Executive Board in favor of his expulsion. The need to preserve a certain morality of the place and the risk resulting from the bad example set by scandalous conduct coming from Mr. James are pointed out as factors for his resignation. The justice or the reparation paid to the worker clearly constitutes a question of second order in the letter quoted below, as she was compensated at the expense of the contractual guarantees of her offender.

In reference to my reserved testimony of 14 and 17 February, I have to tell you that things in relation to the scandal took on another ugly aspect with the subsequent investigations and identifications, which result I refer to you with this comprehensive report. If exclusive property rights had been established, or had I the support of all the shareholders, I would already have shown the road to the perverse Englishman, but not wishing to operate by myself, I consult the Board. .... Dr. Pacífico is of the opinion that the man is completely demoralized, and that he should in no manner continue here. He had the idea of removing him there and hence from this factory. Luis Augusto is of the opinion that the man is of no use to this factory, nor will he be of use to the other one, seeing as how the company is one and the same, and that the man is demoralized, and will even set a bad example. My opinion is as follows: let the perverse fellow be dismissed, and in benefit of the offended party is to be paid the amount he had deposited in guarantee of his contract, seeing as how this lump sum payment costs the company nothing. Thus, she will be married to some other idiot worker and recover her lost or stolen honor. .... I think that he has lost all the qualities required to be general master of the factory, since he not only abused the simplicity of a subordinate simpleton, but also practiced here scandalous acts, which is known by all the inhabitants of the establishment (Textile Co., personal communication, letter signed by the manager of CCC, dated February 25,1889 , box 11A).

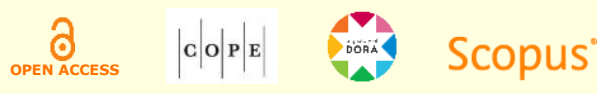




\section{Final Thoughts}

This paper aimed to analyze a certain set of dispositives and discourses that befell southeast Brazilian textile factory working women from late 19th century to the first decades of the 20th century. In this sense, it was possible to evidence a particular set of statements and disciplinary dispositives which in this specific context took women as objects, sculpting the truth from different cross-sections of knowledge. Such discourses constructed an entire field of signification, capable of subsidizing truth effects, fostering the muteness and the deafness that excluded for so long the voice of the other (in this case, the women) from the genesis of statements that dealt with their conditions. In other words, we concluded that, for a long time, women factory workers were prevented from speaking, in fact, they were not allowed to occupy the place of a subject in statements that sought to delimit them as objects.

The social context of inequality that surrounds the potentialities of women, in this case, called for a Foucauldian approach insofar as it showed how the historical reiteration of the control mechanisms surrounding the body contributed for a female subjectification that is based on several discourses such as laws, religion and culture. In this context, we sought to demonstrate how gender can be seen beyond a binary, sexist and biological vision, that is, close to a historical creation of power relations that still involves the female sexed body. We also believe it is important to revisit certain discourses' building patterns that are anchored in supposedly "natural" or biological (Scott, 1995, p. 26) gender differences as a means to deconstruct them and focus on how their regimes of truth work and are actually erected in the historical web.

In accordance to Butler (1993), we also demonstrated how the gendered idea of a female factory worker is strongly built via discourse and performed routinely by the enforced compliance to gendered norms that constrain and constitute a female worker's subjectivity. This path ultimately showed us that an institution such as the convents owned by the Textile Co. have not been consolidated into the void. Not surprisingly, the advent of such an institution correlates to the emergence of a specific set of historically anchored statements, starting in a complex web. Whether it is working women, mother, wife, or Catholic churchgoer, each subject position brings up different intertwining statements that mix, push, pull against each other or remain hidden in a rhizomatic and limitless web of implications. Such statements mostly reflected on women, helping sustain extra-discursive effects such as the gender pay gap, the imposition of the wife/mother/housewife model, the social and legal sanctions for their submission and the denial of their sexuality expression.

It is understood that this paper has also contributed, especially to organizational studies, firstly by appropriating methodological contributions such as historical document analysis (Bowen, 2009; Vizeu, 2010). Such an approach is especially relevant when the documents represent the only or even the best way to access the phenomenon under analysis. Therefore, we expect this paper to contribute to the encouragement of new research agendas that allow researchers to focus on a whole set of documents little or still not explored in our field of knowledge, adopting methodological contributions from historiography not only as a complementary tool, but as a

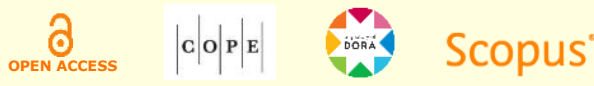


privileged way for a better understanding of the historical processes in the constitution of our research objects.

Another contribution directly related to the previous one, concerns the articulation sought here between the Foucauldian conception of history and the analysis method adopted. In other words, it was possible to move away from the traditional Business History approach, assisting in unveiling a different reality from the one that seeks to reconstruct Management's past, as a field of research, from a sometimes positivist and managerial perspective, focused on novelist biographies of managers, industry captains and their organizations. Instead, taking a critical point of view, we have striven to bring to light the complexity and richness of the power frames present in the context of factory working women, who represent subjects usually erased from organizational archives and marginalized in mainstream discourses of Management Theory. According to Godfrey et al. (2016), the field of organization studies, in turn, lacks this kind of alternative historical perspective since historians do not traditionally consider organizations as a sufficiently relevant object of study. In this way, the importance of works like this is notorious, mainly because it aims at subjective and cultural aspects of the organizations, considering them as foundation of our life in society.

We believe it is important to emphasize that our intention is not to establish a linear and causal relationship between the statements presented and the social practices of the subjects. Even though such correlations may exist, they are derived from an interplay of factors complex enough to not be so easily deciphered. Most importantly, we aimed to evidence the singular existence of such statements, the fact that they have not emerged by chance and that they have been implicated in the reality of these subjects, coveted in the arena of power relations. Moreover, we believe it is essential not to lose sight of the underlying regimes of truth and their powerful effects on the real lives of working women. As real as the harsh conditions of life that marked their trajectories and that allow us to reflect on the seriousness of what it meant to be a poor workingclass, factory working woman in the hinterlands of Brazil, during the transition from the $19^{\text {th }}$ to the $20^{\text {th }}$ century.

\section{Acknowledgements}

The authors would like to thank the Foundation of Supporting Research of Minas Gerais (FAPEMIG), the National Council for Scientific and Technological Development (CNPq) and the Coordination for the Improvement of Higher Level or Education Personnel (CAPES) for their research grant concession, of which this paper is a result. The authors would also like to express their gratitude to the reviewers of the Brazilian Administration Review for the valuable suggestions that have greatly contributed to the improvement of the final version of this paper.

\section{Note}

${ }^{1}$ A conto de réis an old Brazilian idiom equivalent to 1 million Brazilian réis. This currency unit was commonly used in the aforementioned period, circulating until the 1940 s.

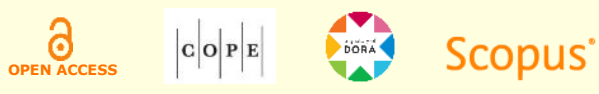




\section{References}

Adamson, M. (2017). Postfeminism, neoliberalism and a 'successfully' balanced femininity in celebrity CEO autobiographies. Gender, Work $\mathcal{E}$ Organization, 24(3), 314-327. https://doi.org/10.1111/gwao.12167

Araújo, I. L. (2008). Foucault e a crítica do sujeito. Curitiba, Brazil: Editora UFPR.

Areimor. (1916, October 19). Aos moços. A Rua, year 1, (13), 1-2, Villa de Paraopeba, MG, Brazil

Arruzza, C. (2015). Considerações sobre gênero: Reabrindo o debate sobre o patriarcado e/ou capitalismo. Revista Outubro, 23, 33-58. Retrieved from http://outubrorevista.com.br/wpcontent/uploads/2015/06/2015_1_04_Cinzia-Arruza.pdf

Barros, A. N. (2013). Uma narrativa sobre a história dos cursos de administração da FACE-UFMG: Às margens do mundo e à sombra da FGV? (Tese de doutorado). Centro de Pós-Graduação e Pesquisas em Administração, Universidade Federal de Minas Gerais, Belo Horizonte, MG, Brasil.

Boris, G. D. J. B., \& Cesídio, M. de H. (2007). Mulher, corpo e subjetividade: Uma análise desde o patriarcado à contemporaneidade. Revista Mal-Estar e Subjetividade, 7(2), 451-478. Retrieved from http://pepsic.bvsalud.org/pdf/malestar/v7n2/12.pdf

Bowen, G. A. (2009). Document analysis as a qualitative research method. Qualitative Research Journal, 9(2), 27-40. https://doi.org/10.3316/QRJ0902027

Bruschini, M. C. A. (2007). Trabalho e gênero no Brasil nos últimos dez anos. Cadernos de Pesquisa, 37(132), 537 572. http://dx.doi.org/10.1590/S0100-15742007000300003

Butler, J. (1993). Critically queer. GLQ: A Journal of Lesbian and Gay Studies, 1(1), 17-32. https://doi.org/10.1215/10642684-1-1-17

Cappelle, M. C. A. (2006). O trabalho feminino no policiamento operacional: Subjetividade, relações de poder e gênero na oitava região da PMMG (Tese de doutorado). Centro de Pós-Graduação e Pesquisas em Administração, Universidade Federal de Minas Gerais, Belo Horizonte, MG, Brasil.

Cappelle, M. C. A., \& Melo, M. C. O. (2010). Mulheres policiais, relações de poder e de gênero na polícia militar de Minas Gerais. Revista de Administração Mackenzie, 11(3), 71-99. https://doi.org/10.1590/s1678. 69712010000300006

Carrieri, A. P., Diniz, A. P. R., Souza, E. M., \& Menezes, R. S. S. (2013). Gender and work: Representations of femininities and masculinities in the view of women Brazilian executives. BAR - Brazilian Administration Review, 10(3), 281-303. https://doi.org/10.1590/s1807-769220130050000002

Clark, P., \& Rowlison, M. (2004). The treatment of history in organization studies: Towards an 'historic turn'? Business History, 46(3), 331-352. https://doi.org/10.1080/0007679042000219175

Delphy, C. (2009). Patriarcado (teorias do) (T. Godinho, Trad.). In H. Hirata, F. Laborie, H. L. Doaré, \& D. Senotier (Orgs.), Dicionário crítico do feminismo (pp. 173-178). São Paulo, Brazil: Editora UNESP.

Duffy, K., Hancock, P., \& Tyler, M. (2017). Still red hot? Postfeminism and gender subjectivity in the airline industry. Gender, Work and Organization, 24(3), 260-273. https://doi.org/10.1111/gwao.12147

Dwivedi, P., Joshi, A., \& Misangyi V. F. (2018). Gender-inclusive gatekeeping: How (mostly male) predecessors influence the success of female CEOs. Academy of Management Journal, 61(2), 379-404. https://doi.org/10.5465/amj.2015.1238

Fairclough, N. (1992). Discurso e mudança social (I. Magalhães, Trad.). Brasília, Brazil: Editora Universidade de Brasília.

Fonseca, M. A. da. (2001). Foucault e o direito (Tese de doutorado). Faculdade de direito, Universidade de São Paulo, São Paulo, SP, Brasil.

Foucault, M. (1977). Discipline and punish: The birth of the prison (A. Sheridan, Trans.). New York, NY: Phanteon Books.

Foucault, M. (1979). Truth and power: An interview with Michel Foucault. Critique of Anthropology, 4(13-14), 131 137. https://doi.org/10.1177/0308275X7900401311.

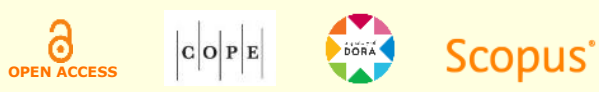


Foucault, M. (1990). History of sexuality vol. II: The use of pleasure. New York, NY: Vintage Books.

Foucault, M. (1992). Microfísica do poder (R. Machado, Org., Trad.). Rio de Janeiro, Brazil: Editora Graal.

Foucault, M. (2003). Society must be defended: Lectures at the College De France, 1975-76. New York, NY: Picador.

Foucault, M. (2008). The archeology of knowledge. New York, NY: Pantheon Books.

Foucault, M. (2009). Security, territory, population: Lectures at the College De France, 1977-78. London, UK: Palgrave Macmillan.

Giroletti, D. (1991). Fábrica, convento e disciplina. Belo Horizonte, Brazil: Imprensa Oficial.

Godfrey, P., Hassard, J., O’Connor, E., Rowlinson, M., \& Ruef, M. (2016). What is organizational history? Toward a creative synthesis of history and organization studies. Academy of Management Review, 41(4), 590-608. https://doi.org/10.5465/amr.2016.0040

Kanze, D., Huang, L., Conley, M. A., \& Higgins, E. T. (2017). We ask men to win and women not to lose: Closing the gender gap in startup funding. Academy of Management Journal, 61(2), 586-614. https://doi.org/10.5465/amj.2016.1215

Lei n. 3.071, de $1^{\circ}$ de janeiro de 1916. (1916). Revogada pela Lei n. 10.406, de 2002. Retrieved from http://www.planalto.gov.br/ccivil_03/leis/13071.htm

Leslie, L. M., Manchester, C. F., \& Dahm, P. C. (2017). Why and when does the gender gap reverse? Diversity goals and the pay premium for high potential women. Academy of Management Journal, 60(2), $402-432$. https://doi.org/10.5465/amj.2015.0195

Lewis, P., Benschop, Y., \& Simpson, R. (2017). Postfeminism, gender and organization. Gender, Work Ë Organization, 24(3), 213-225. https://doi.org/10.1111/gwao.12175

Lima, J. de S. (2009). De meninas fiandeiras a mulheres operárias: A inserção da mão-de-obra feminina na Companhia de Fiação e Tecidos Cedro e Cachoeira (1872 -1930) (Dissertação de mestrado). Centro Federal de Educação Tecnológica de Minas Gerais, Belo Horizonte, MG, Brasil.

Maclean, M., Harvey, C., \& Clegg, S. R. (2016). Conceptualizing historical organization studies. Academy of Management Review, 41(4), 609-632. https://doi.org/10.5465/amr.2014.0133

Meyer, D. (1996). Do poder ao gênero: Uma articulação teórico-analítica. In M. J. M. Lopes, D. E. Meyer, \& V. R. Waldow (Orgs.), Gênero e saúde (pp. 41-54). Porto Alegre, Brazil: Artes Médicas.

Moraes, M. Q. de. (1981). Família e feminismo. Cadernos de Pesquisa, 37, 44-51. Retrieved from http://publicacoes.fcc.org.br/ojs/index.php/cp/article/view/1594/1583

Poster, M. (1979). Teoria crítica da família. Rio de Janeiro, Brazil: Editora Zahar.

Rago, M. (2007). Relações de gênero e classe operária no Brasil: 1890-1930. In A. Piscitelli, H. P. de Melo, S. W. Maluf, \& V. L. Puga (Eds.), Olhares feministas (pp. 219-237). Brasília, Brazil: Ministério da Educação.

Rey, F. G. (2005). Pesquisa qualitativa e subjetividade: Os processos de construção da informação. São Paulo, Brazil: Pioneira Thomson Learning.

Rowlinson, M., Hassard, J., \& Decker, S. (2014). Research strategies for organizational history: A dialogue between historical theory and organizational theory. Academy of Management Review, 39(3), $250-274$. https://doi.org/10.5465/amr.2012.0203

Rubin, G. (1990). The traffic in women: Notes on the 'political economy' of sex. In K. Hansen, \& I. Philipson (Eds.), Women, class, and the feminist imagination (pp. 74-113). Philadelphia, PA: Temple.

Rubin, G. (2003). Pensando o sexo: Notas para uma teoria radical das políticas de sexualidade. Retrieved from http://www.miriamgrossi.cfh.prof.ufsc.br/pdf/gaylerubin.pdf

Sangster, J., \& Smith, J. (2016). Beards and bloomers: Flight attendants, grievances and embodied labour in the Canadian airline industry, 1960s-1980s. Gender, Work and Organization, 23(2), 183-199. https://doi.org/10.1111/gwao.12120

Santos, N. A. (2016). A divisão sexual do trabalho na agricultura familiar: Entre a invisibilidade e a desvalorização do trabalho (re) produtivo de mulheres trabalhadoras rurais do município de Brejo/MA frente à expansão da

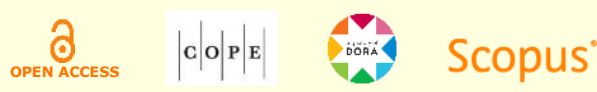


monocultura de soja. Revista de Políticas Públicas, 20, 331-337. http://dx.doi.org/10.18764/2178. 2865.v20nEp331-338

Santos, L. C. dos, Carvalho, A. B., Amaral, J. G., Borges, L. A., \& Mayorga, C. (2016). Gênero, feminismo e psicologia social no Brasil: Análise da revista Psicologia \& Sociedade (1996-2010). Psicologia Ë Sociedade, 28(3), 589-603. https://doi.org/10.1590/1807-03102016v28n3p589

Sardenberg, C. M. B. (1997). In the backyard of the factory: Gender, class, power and community in Bahia, Brazil (PhD dissertation). Boston University, Boston, MA, USA.

Scott, J. (1995). Gênero: Uma categoria útil para análise histórica. Educação E̊ Realidade, 20(2), 71-99. Retrieved from https://seer.ufrgs.br/educacaoerealidade/article/view/71721/40667

Silva, J. B. (1934). Buena-dicha. Belo Horizonte, Brazil: Imprensa Oficial.

Silva, P. M. M., Rocha, M. P., Neto, Brito, L. M. P., Barreto, L. K. S., \& Gurgel, F. F. (2016). Equidade de gênero nas organizações: $\mathrm{O}$ trabalho e os desafios da mulher na construção civil. Revista Organizações em Contexto, 12(24), 283-305. https://doi.org/10.15603/1982-8756/roc.v12n24p283-305

Souza, E. M., Brewis, J., \& Rumens, N. (2016). Gender, the body and organization studies: Que(e)rying empirical research. Gender, Work E Organization, 23(6), 600-613. https://doi.org/10.1111/gwao.12145

The dowry of a girl without dowry. (1922, May 14). Gazeta de Paraopeba, year 12, (690), Paraopeba, MG, Brazil.

Thiry-Cherques, H. R. (2003). Condição feminina e percepção dos valores morais no nível gerencial e técnicos das organizações brasileiras. Revista de Administração Pública, 37(2), 477-511. Retrieved from http://app.ebape.fgv.br/comum/arq/ACF7B.pdf

Vaz, A. M. (2005). Bernardo Mascarenhas: Desarrumando o arrumado - um homem de negócios do século XIX. Minas Gerais, Brazil: Editora O Lutador.

Vieira, A., Carrieri, A. P., Monteiro, P. R. R., \& Roquete, F. F. (2017). Gender differences and professional identities in health and engineering. BAR - Brazilian Administration Review, 14(1), e160082. https://dx.doi.org/10.1590/1807-7692bar2017160082

Vizeu, P. (2010). Potencialidades da análise histórica nos estudos organizacionais brasileiros. Revista de Administração de Empresas, 50(1), 37-47. https://doi.org/10.1590/s0034-75902010000100004

\section{Author contributions}

$1^{\text {st }}$ author: conceptualization (lead), data curation (lead), formal analysis (lead), funding acquisition (equal), investigation (lead), methodology (lead), resources (equal), writing-original draft (lead), writing-review and editing (equal).

$2^{\text {nd }}$ author: formal analysis (supporting), funding acquisition (equal), methodology (supporting), resources (equal), writing-original draft (supporting), writing-review and editing (equal).

$3^{\text {rd }}$ author: formal analysis (supporting), funding acquisition (equal), methodology (supporting), resources (equal), writing-original draft (supporting), writing-review and editing (equal). 


\section{Authors}

\section{Rafael Diogo Pereira}

Universidade Federal de Minas Gerais, Faculdade de Ciências Econômicas Avenida Antônio Carlos, 6627, sala 4067, 30170-120, Belo Horizonte, MG, Brazil rdp.ufmg@gmail.com

(iD) https://orcid.org/0000-0002-1057-2614

\section{Andressa Carolina do Nascimento Nunes}

Universidade Federal de Minas Gerais, Faculdade de Ciências Econômicas Avenida Antônio Carlos, 6627, 30170-120, Belo Horizonte, MG, Brazil acnnunes@ufmg.br

(iD) https://orcid.org/0000-0002-7861-0314

\section{Thaís Zimovski Garcia de Oliveira}

Universidade Federal de Minas Gerais, Faculdade de Ciências Econômicas Avenida Antônio Carlos, 6627, 30170-120, Belo Horizonte, MG, Brazil thais.zimovski@yahoo.com.br

(iD) https://orcid.org/0000-0003-1130-0810 